\title{
The Right of Search Controversies, 1839-1842 and 1857-1858
}

\section{Rodney Carlisle}

Cet article s'adresse aux différends entre les Etats-Unis et la GrandeBretagne au sujet du "droit de fouille " des navires marchands américains pendant les périodes 1839-42 et 1857-58. La question s'est posée quand l'escadron britannique anti-esclavage a arrêté des navires présumés négriers qui naviguaient sous pavillon américain, et les a inspecté pour déterminer si leur documentation était en règle et s'ils étaient en fait des négriers. Les Etats-Unis ont protesté, et le problème a été apparemment résolu en 1842; néanmoins, il a refait surface quinze ans plus tard. La visibilité croissante et décroissante de cette question reflète les changements des personnalités à la direction du gouvernement de la Grande-Bretagne et les États-Unis, et reflète également la puissance persistante des questions entourant l'utilisation du drapeau marchand américain en mer, souvent vue comme question d'honneur national.

The issue at the heart of this topic was politically divisive, both in the United States and in Great Britain. At its height in 1841, the controversy began to take shape as one of several possible casus belli for a third war between Great Britain and the United States over maritime issues. After the issue was apparently resolved in 1842, it lay dormant for some 15 years, to again surface in 1857 and 1858 . This paper examines how and why the issue arose, how serious it was, how and why it was temporarily resolved, and why it revived again so unexpectedly in the late 1850s. Although the maritime issue was only one of several aspects of the tensions between the United States and Britain, the controversy revealed that "affronts to the flag" at sea continued to contribute to sentiments in favor of war in the United States.

Although a possible war between the United States and Britain loomed in the early 1840 s, later British/United States amity has tended to paint a somewhat rosy textbook impression (not supported in historical scholarship) that depicts U.S.-British harmony beginning in 1816. John Bull and Uncle Jonathan were at each other rather continuously between the War of 1812, through the period of the U.S. Civil War and into Reconstruction. The episodes of conflict between U.S and Great Britain have been somewhat expunged (if not literally, then at least stylistically) from these decades of history in a rather "Orwellian" double-think or right-think tendency to reshape history to fit contemporary (i.e. 20th and 21st century) alliances. Anglo-American harmony can only be traced to the 1872 resolution of the Alabama claims after the Civil War. 
As we look closely at the events at the core of the "Right of Search" controversies, we find a set of maritime issues very similar to those that constituted one of the casus belli for the War of 1812. In particular, the British impressing of seamen from U.S. ships, including the 1807 Chesapeake incident, was a crucial casus belli for the War of 1812. Even though sentiment in favor of that war was strongest in western, nonseaport regions, and weakest in maritime New England, the issue had provided a rallying cry over the "outrages" committed by the British, providing rhetorical ammunition supporting the claim of British disregard for American national status. The treaty that resolved that war did not include a clause prohibiting searching of ships in peacetime in the future.

The British regarded such an explicit prohibition as unnecessary or redundant. Searching a foreign merchant ship in international waters during peacetime was a practice not even countenanced in British law unless the ship flew a flag of a nation that entered a treaty allowing such a search. Impressing of seamen had been conducted under the wartime "Right of Search," during the Napoleonic wars; but in 1839-1840 Britain was exercising a "Right of Search" in time of peace. Under so-called "international Law," and from the American viewpoint, Britain had absolutely no right to permit or order its warships to detain, inspect, or board ships flying the U.S. flag in international waters in peacetime.

As we will see, British warships did in fact stop and detain many merchant ships flying the American flag and British officers then boarded the ships to inspect documentation to verify whether or not the ships were entitled to fly the flag, all in the name of putting an end to the slave trade. The British claimed that the detention, visitation, and search and some seizures were all done in order to determine proper documentation of the ship's right to fly the U.S. flag. That is, slavers often simply adopted a false flag with no proper right to it, and the detentions and searches off the coast of Africa were intended to root out such false-flag ruses, the British claimed. ${ }^{1}$

An earlier article in The Northern Mariner showed how the "maritime code duello" in the United States affected foreign policy. The maritime code duello reflected the masculine honor code that regulated the issues of insult and challenges to duels in the early 19th century; that same honor code shaped American responses to "affronts" and "outrages" at sea. Similar values lay behind the heated rhetorical responses in the 1840s and 1850 s to these episodes arising from the British practice of stopping U.S. flagged vessels. ${ }^{2}$ Editorialists and some officials urged the United States to avenge or protect its flag because it was being regularly "insulted" by such searches. The searches, they claimed, showed British contempt and failure to treat the United States as an equal.

The issue of the Right of Search of suspected slave-trade ships first arose at the same time that a simmering border dispute over the boundary between the British colony of New Brunswick and the state of Maine threatened to provide another major casus belli

$1 \quad$ New York Times, 8 December 1860.

2 Rodney Carlisle, "The American Maritime Code Duello," The Northern Mariner XXI (April 2011), 159. 
- the so-called Aroostook War controversy. The state of Maine planned a militia to enter the disputed zone and unilaterally adjust the boundary by force of arms, and the New Brunswick colonists also prepared their local militia. As this border issue threatened to boil over into armed conflict, the American anti-British press focused on the British "outrages" at sea arising out of the slave trade issue, linking the obscure boundary question of local interest to the more nationally inflammatory issue of outrageous insults to the national flag. ${ }^{3}$

The United States had outlawed the importation of slaves to the United States in 1807.To prevent slave export from Africa by American ships, the United States provided naval ships to patrol off West Africa, beginning with the USS Cyane in 1820. Off the coast of Africa, U.S. captures went to Monrovia, Liberia where the American Colonization Society administered a colony for resettled African-Americans; British captures went to Freetown, Sierra Leone, where commissions would rule whether there was sufficient evidence of slave trading to condemn the ship and award prize money to the capturing ship. Some Liberian ships cooperated with both the British and American squadrons in suppression of the trade under the American Colonization Society's Liberian Governor Thomas Buchanan (1839-41). ${ }^{4}$ However, there was very limited cooperation between the British and American squadrons, except for occasional agreements between British and American officers about the handling of particular captured ships.

Until the late 1830s, the British refrained from confiscating slave ships off West Africa unless there were actually slaves aboard; that is, an empty slave-ship, outfitted for the trade, flying the flag of Spain or Portugal, could not be confiscated in the early period. In 1835 Spain agreed that ships outfitted for the trade under her flag could be seized even if they carried no slaves; Portugal agreed to the same principles in 1836. British captains immediately began stopping and seizing suspected slave ships that sailed under those flags and taking them to Freetown for adjudication. The chronology is shown in Table 1.

Table 1: Chronology of International Slave Ship Treaty and Law

1817 Portugal concedes the Right of Search to Britain

1831 Brazilian Empire accepts 1817 Portuguese-British Right of Search terms

1835 Spain concedes Right of Search; establishes Mixed Commission, allows condemnation of ships equipped for slave trade

3 There is an interesting and growing literature on the Aroostook War controversy. See Francis Carroll, "The Passionate Canadians: The Historical Debate about the Eastern CanadianAmerican Boundary," New England Quarterly 70 (March 1997),83-101. It is quite likely that the map produced by Jared Sparks from the French archives was fraudulent, designed to allay the concerns of the Maine legislature. On the other hand, a website which defends the Red Line map as genuine is www.upperstjohn.com/history/northernborder.htm

4 Liberian Governor Thomas Buchanan's support was noted in the popular press at the time, and is documented in Archibald Alexander, Colonization on the West African Coast (1846; repr. Negro Universities Press, 1969), 572 ff. 


\begin{tabular}{|l|l|}
\hline 1836 & Portugal authorizes condemnation of ships equipped for slave trade \\
\hline 1839 & $\begin{array}{l}\text { Chile and Venezuela concede Right of Search, establish Mixed Commissions, allow } \\
\text { confiscation of ships equipped for slave trade; British pass law authorizing British } \\
\text { cruisers to detain Portuguese ships and condemn them }\end{array}$ \\
\hline 1841 & $\begin{array}{l}\text { In the Quintuple Treaty, Austria, France, Prussia, and Russia authorize condemnation } \\
\text { by the British of ships equipped for the trade; the four continental powers do not } \\
\text { concede Right of Search, but specifically allow visitation to determine accuracy of } \\
\text { papers }\end{array}$ \\
\hline 1842 & $\begin{array}{l}\text { Webster-Ashburton Treaty between the United States and Britain signed; does not } \\
\text { explicitly address right of search issues }\end{array}$ \\
\hline
\end{tabular}

Source: www.royalnavalmuseum.org/visit_see_victory_cfexhibition_timepost1807.htm

By the late 1830s, some of the Spanish slave traders' ships adopted the false use of the U.S. flag, especially when there were no slaves aboard, thereby hoping to avoid British inspection; as a consequence, over the period 1839-1841, at least five (and probably more) ships bearing the U.S. flag were stopped, and some were found to be in fact Spanish-owned slavers and slave-equipped ships, falsely flying the flag. These were the ships that caused the most distress at the height of the 1841 controversy, shown in Table 2.

Table 2: U.S. ships searched by British West African anti-slavery Squadron, 1839-1841

\begin{tabular}{|l|l|l|l|l|}
\hline \multicolumn{1}{|c|}{ U.S. ship } & \multicolumn{1}{|c|}{ US captain } & \multicolumn{1}{c|}{ Type } & British Ship & \multicolumn{1}{c|}{ British Commander } \\
\hline Douglass & Alvin Baker & brigantine & Termagant & Lt. Henry Frowd Seagram \\
\hline Susan & & brig-sloop & Grecian & Cdr. William Smyth \\
\hline Mary & D.Tomlinson & brigantine & Forester & Lt.Cr. Colin Yorke Campbell \\
\hline Iago & Adolphus Dupony & brigantine & Termagant & Lt. Henry Frowd Seagram \\
\hline Hero & B. McConnell & brigantine & Lynx & Lt. Cr. Henry Broadhead \\
\hline
\end{tabular}

Sources. Compiled from the following reports: Douglass:NY Herald, 10 November 1841, 241 col. C; Penn. Inquirer \& Daily Courier, 16 December 1841; Niles' National Register (18371849), 18 December 1841, 11, 16; The Weekly Herald (New York, NY), 13 November 1841; Susan and Mary: Niles' National Register (1837-1849), 18 December 1841; Iago and Hero: Boston Courier, 16 December 1841; Royal Navy details: website re British Squadron: http://home.wxs.nl/ pdavis/index.htm

The U.S. minister to England, Andrew Stevenson, protested vehemently against the British assumption of the right of search in these five cases, even though there was no way to determine if the flag was legitimate without examining the ship papers. An exchange of diplomatic notes (often in not very diplomatic language) followed. In newspapers in the United States, some editorialists opined that the right of search issue would become a casus belli and linked it to the Northeastern "Aroostook" Boundary issue as part of the growing package of war-causes.

The issue was divisive on both sides of the Atlantic. The responsible individuals 


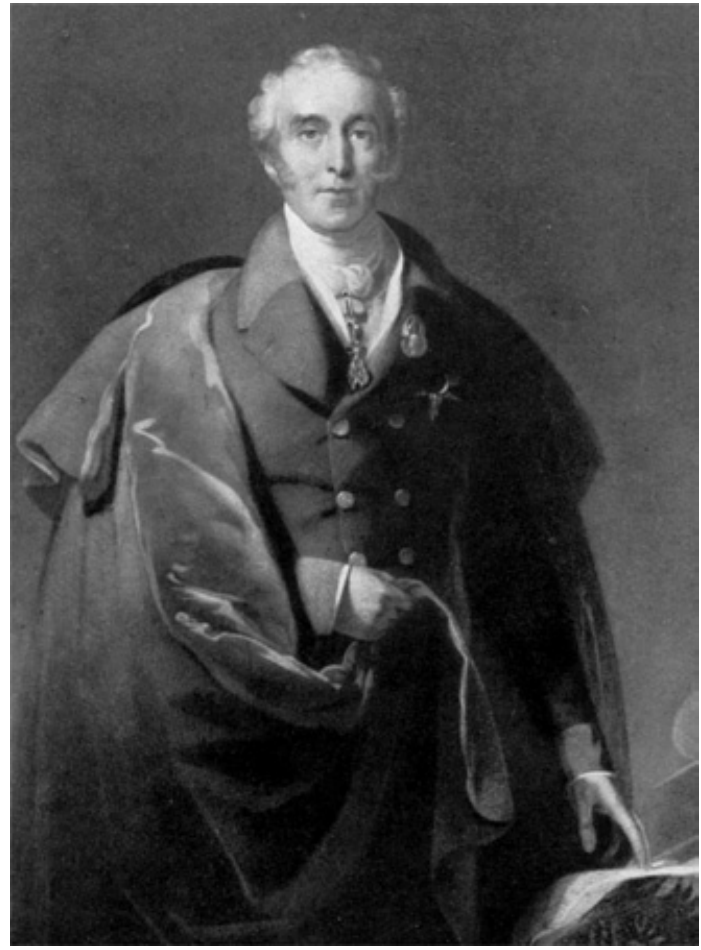

Arthur Wellesley, Duke of Wellington, from a painting by J. Lilley. Naval Marine Archive. in both governments contributed their personal tone to the debate: on the side of the United States, Stevenson, Lewis Cass, and Daniel Webster; on British side, lords Palmerston, Wellington, and Ashburton. Among the most vehement defenders of the U.S. position were Stevenson and Cass. On the British side, Wellington and Ashburton were conciliatory, Palmerston was more intolerant of the U.S. position. ${ }^{5}$

From the British perspective, the core issue was this: how could the British officers determine if a ship flying the U.S. flag was entitled to do so, unless they searched the ship and looked at the documents? But under "international law," established precedent, and traditional British practice, such a right existed only during war, unless specifically conceded by treaty. In 1841 , the United States took the position that only U.S. authorities had the right to investigate and punish false uses of the

U.S. flag. If the slave trade went on under false flags, that was less important than the affront to U.S. honor of British naval officers exerting a "right" to stop and search ships flying the U.S. flag. The U.S. objection may seem rather technical now, but that fact simply illustrates the sensitivity over national "honor" that such an issue could evoke in the era. As a practical matter, the British held, it was the best way to interdict the trade. U.S. officials and editorialists who opposed the British practice explicitly said that they believed that Britain would exert the right for covert reasons: a) to interfere with legitimate U.S. African trade; b) to impress naturalized American citizens into the British Royal Navy; and c) to arrogantly and illegally insult the national honor of the United States. There was a small sector of the U.S. press, such as William Lloyd Garrison's Liberator and other anti-slavery or pro-British papers, that suggested the British were simply being practical. ${ }^{6}$

$5 \quad$ Full text at “The Right of Search," Niles' National Register (1837-1849), 26 March 1842, 12, 4.

6 In addition to the anti-slavery press, the avowedly pro-British press also supported the exercise of the Right of Search on suspected slave ships. During the 1850s, the Anglophile Albion favored the British practice; the New York Times, although maintaining an "objective" tone, tended to show the logic of the British position, while also showing that, from the American point of view, the question of national honor was at stake. Generally, Northern Whigs (and later, Republicans) tended to be more accepting of the British position, 
Those editorialists expressing a hostile reaction to the British apparent exercise of the right of search during peacetime explicitly and repeatedly evoked the War of 1812 precedents and the issue of American honor. Clearly for many Americans, the issue of British arrogance and trampling on American maritime rights was of far greater importance than stopping the slave trade to Cuba, Puerto Rico, or Brazil. Furthermore, Britain had treaties with Spain, Portugal, Brazil, some Spanish American republics, and by 1841, also with France, Austria, Prussia, and Russia, that either explicitly conceded the right of search or made arrangements for visitation to verify documents. However, Britain had no such treaty with the United States. The British acted as though they needed treaties with European and Latin American nations, but could dispense with treaties when dealing with the United States. With that differential treatment in mind, it is easy to see how British actions appeared insulting; America's status as a nation among nations was being "disrespected."

Then, in 1842 , the issue rather suddenly subsided for a period. Why? Several factors coalesced. a) William Henry Harrison (known as an anti British general from the War of 1812, famous for his victory at Tippecanoe) died after thirty days in office in March-April 1841; Vice President John Tyler took over. Tyler, like Lewis Cass and Andrew Stevenson, was also a War of 1812 veteran although not a "hero" of that war. Even so, Tyler was less doctrinaire in his anti-British position than Harrison, although he was a strong pro-southern States Rights Whig and a slave holder; he was in a weak position as "his Accidency," needing to establish whether a succeeding vice president became president or whether he was merely "acting." Tyler set the precedent for "becoming president" not legalized until the 25th Amendment to the Constitution in 1967. b) The Webster-Ashburton treaty, which established a new Maine-New Brunswick border, was signed 9 August 1842. The treaty further established reciprocity of extradition for crimes and also explicitly stated that naval officers on anti-slavery patrol would be instructed to cooperate on the spot. While the treaty did not concede the right of search in peacetime, it did seem a step towards resolution of the issue. c) The Aroostook Boundary issue was resolved when members of the Maine state legislature received copies of a "Red Line" map; this was a map conveniently "found" in French archives, purporting to show the British boundary claim supported by Benjamin Franklin in 1783. Maine legislators who threatened to fund a state militia to attack Canada backed down on being shown the map. d) Personnel changed. This factor may be the most striking contributor to the reduction of tensions. Several of the most hostile individuals on both sides of the Atlantic were replaced by more conciliatory men.

From the British perspective, there were several additional reasons for the controversy over the right of search to recede. Between 1815 to 1851 the British government faced major problems in adjusting to a peacetime economy that was increasingly urban and industrial. Its response included the abandonment of the Navigation Laws in 1848 and nine major revisions of trade duties in $1860 .^{7}$ Eric

Democrats tended to a more nationalist and "outraged" position.

7 Colin Matthew, The Nineteenth Century: The British Isles, 1815-1900 (New York: Oxford University Press, 2000), 48. 
Hobsbawm has pointed out that "the years from 1848 to the mid 1870s saw Britain involved in considerably more warfare than the preceding thirty or succeeding 40 years." These incidents were "either brief operations decided by technological and organisational superiority... or mismanaged massacres on which even the patriotism of the belligerent countries has refused to dwell with pleasure, such as the Crimean War 1854-6..." ${ }^{8}$ With such pressures, the British did not seek, nor want, a disastrous conflict with the United States, in which Canada would be subject to invasion.

President Tyler replaced U.S. minister to Britain Andrew Stevenson. Stevenson was a hot-headed pro-slavery Democrat from Virginia and himself the owner of slaves. As an insight into Stevenson's viewpoint and his character, it is pertinent that Daniel O'Connell, the internationally famous Irish leader and anti-slavery writer, publicly accused Stevenson of being a "slave-breeder"; Stevenson made steps to challenge O'Connell to a duel, but O'Connell did not accept the challenge, and offered a backhanded "clarification" of his public statement. O'Connell had earlier fought a duel, and

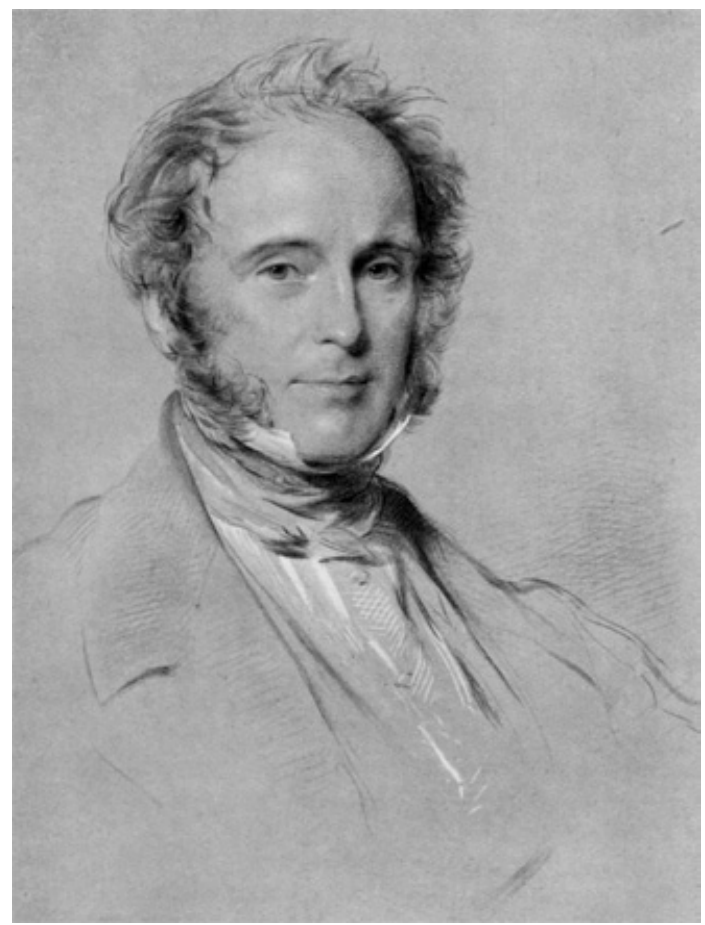

Henry John Temple, 3rd Viscount Palmerston, from a drawing by G. Richmond. Naval Marine Archive. had felt remorse at killing his opponent, so no duel was fought. ${ }^{9}$ Stevenson's replacement, Edward Everett, was a proBritish, Massachusetts Whig. If cases came up, Everett would not be inclined to raise them to the level of diplomatic note exchanges.

Lord Palmerston (who was a rather contemptuous of U.S. claims to rights of various kinds) was out by 1842 ; Lord Wellington (who was very conciliatory to the United States) was now leader of the House of Lords, commander-in-chief in the British army and minister without portfolio under Peel; further, Alexander Baring (Lord Ashburton), sent to Washington to negotiate as a minister with plenipotentiary powers, was also more conciliatory, as was U.S. Secretary of State Daniel Webster. Webster, Tyler's secretary of state (inherited from Harrison), was, like Everett, a Massachusetts Whig, and a leading

8 Eric Hobsbawm, The Age of Capital 1848-1875 (New York: Charles Scribner's Sons, 1975), 15-16.

9 Christine Kinealy, “The Liberator: Daniel O'Connell and Anti-Slavery," History Today 57, no. 12 (2007). Kinealy erred by claiming Stevenson was not a slave owner; see also the more detailed: Howard Temperly: "The O'Connell-Stevenson Contretemps: A Reflection on the Anglo-American Slavery Issue," Journal of Negro History (October 1962). 
advocate of North-South compromise. Furthermore Daniel Webster had been an opponent of the War of 1812. Like other conservative Massachusetts Whigs, he sought to avoid war with Britain, and was tolerant of, but not a defender of, slavery. So cooler heads prevailed on both sides of the Atlantic.

Even so, some spokesmen for a strong anti-British position on the issue continued in office. Cass served as U.S. minister to France into 1842. There he published a pamphlet that was intended to persuade French deputies not to concede the right of search in the so-called Quintuple (five-power) Treaty. ${ }^{10}$ Cass was a "popular sovereignty" supporter of the right of U.S. slaveholders to hold slaves and a strong defender of U.S. honor when it came to British insults. His pamphlet, although wellreceived among some anti-British French deputies, did not prevent the French from signing the treaty which conceded a detailed right of visitation to help suppress the slave trade, although not a formal right of search. When the French did not include a distinct denial of the right of search in their acceptance of the Quintuple Treaty, Cass resigned his position as minister to France, claiming that the French decision and the WebsterAshburton Treaty "compromised his position." 11

The British interpreted clause 8 of the Webster-Ashburton Treaty which established cooperation in the anti-slavery patrol on the squadron level as "conceding the Right of Search" but President Tyler declared emphatically that no such right was conceded. In the Senate, Senator Thomas Hart Benton, staunch Democrat and another outspoken defender of national honor, roundly criticized the Whig Webster for giving in to Britain. ${ }^{12}$

In response to Benton's criticism, Webster released to the press a letter he sent to Minister Everett in Britain, showing that he did not regard the treaty as conceding any "right" to search or visitation, and at the same time indicated that he thought the cooperation of naval officers on the scene would put an end to false flag uses. ${ }^{13}$ In effect, Webster was claiming that the treaty resolved the issue, and at the same time publicly and officially stated to Britain that no right had been conceded. He tried to have his cake and eat it too. It seemed to work.

The Webster-Ashburton treaty had settled the boundary dispute with Canada, and with the changes in personnel, the right of search issue subsided. Over the following years, the news media in the United States turned to other concerns - the admission of Texas, the war with Mexico, the Gold Rush, the Compromise of 1850, and the burning

10 Lewis Cass' pamphlet was: “An Examination of the Questions Now in Discussion between the American and British Governments Concerning the right of Search." The pamphlet was widely circulated in Britain and France, and reprinted in U.S. newspapers. See also William Carl Kluger, Lewis Cass and the Politics of Moderation (Kent, Ohio: Kent State University Press, 1996), 106-107.

11 W.E.B. DuBois, The Suppression of the African Slave Trade to the United States of America, 1638-1870, Harvard Historical Studies (New York: Longmans, Green and Co, 1896), note 62 to chapter 9 .

12 Pennsylvania Inquirer and National Gazette (Philadelphia, PA), 23 February 1843.

13 Fayetteville Observer (Fayetteville, NC), 12 April 1843. 
issue of slavery in the Federal territories.

Over the period from 1840 to 1856, the United States' West African Squadron (and other U.S. government and naval vessels) successfully seized and condemned at least 15 slave ships, and destroyed another 13 at sea. ${ }^{14}$ Some of them had been using the U.S. flag as a false flag. Since U.S. naval ships were not allowed to detain any ships "equipped" for the trade but only those with slaves aboard, often a slave transport ship so equipped would fly the U.S. flag as it approached the African coast, then, after loading slaves, the ship would be "sold" to a Spanish citizen and a Spanish flag hoisted, and then the ship would sail past the American squadron, which had no agreement with Spain to interdict such ships. The Royal Navy could stop the Spanish-flagged ships, but U.S. naval officers were powerless to do so. ${ }^{15}$

Few scholars have offered interpretations for the decline of the issue in the mid 1840 s to the late 1850 s. Historian W.E.B. DuBois, writing in 1896, suggested that one reasons was that Congressmen would not come to the defense of U.S. flagged slave ships because the detentions had "revealed so much American guilt that it was deemed wiser to let the matter end in talk." Du Bois pointed out that in 1850, an investigation by the Fillmore administration showed that out of ten American-flagged ships detained by the British, nine were proven to be slavers. ${ }^{16}$

However, after the issue had lain dormant for years, in 1857-1858, the British searched and detained several more U.S. ships flying the U.S. flag, and the issue once again raised tempers. ${ }^{17}$ In these two years at least another 15 U.S. ships were boarded or visited by British officers, off West Africa and also in the West Indies, and numerous U.S. ship masters filed complaints or reports in the United States. Again, Lewis Cass, now secretary of state under President James Buchanan, took the lead in protesting the infringement of U.S. rights, clarifying once again that the U.S. had NOT conceded the Right of Search in the Webster-Ashburton Treaty. On 10 April 1858, he sent the following note to Lord Napier, British minister in Washington, reflecting the issue of national honor:

To permit a foreign officer to board the vessel of another power to assume command of her, to call for and examine her papers, to pass judgment upon her character ...to send her in at pleasure for trial, cannot be submitted to by any independent nation without injury and dishonor. The United States deny the right of the cruisers of any other power whatsoever, for any purpose whatsoever, to enter their vessels by force in time of peace. ${ }^{18}$ [Italics in original.]

The relative disappearance of the issue after 1843, and its sudden reappearance in

14 http://en.wikipedia.org/wiki/Africa_Squadron This Internet site shows some 16 ships captured by 1859

15 DuBois, p. 162, note 35: Papers Relative to the suppression of the Slave Trade on the Coast of Africa, p. 13.

16 Dubois, p. 166, note 60, citing Senate Exec Doc, 31 Congress, 1 session XIV, no 66.

17 "The British Aggressions," New York Times, 4 June 1858.

18 "The Question of Search," New York Times, 17 May 1858. 
1857-1858 is striking. Several developments may together account for the revival of controversy. 1) There was another change in personnel. Not only was Cass back in a lead position, but, in Britain, Palmerston, back in the cabinet, was more aggressive on this score than others and he was reputed to be emboldened by the British election results of March 1857. ${ }^{19}$ 2) There was a resurgence of actual slave transportation in the West Indies due to increased price levels for slaves in the United States and Cuba. ${ }^{20}$ 3) News reports showed the outfitting of an estimated 40 to 85 U.S.-built ships a year through the 1850s to engage in the trade,raising the number of ships involved and leading to more episodes. ${ }^{21}$ 4) The equipping of the Royal Navy with steam-powered warships meant that they could then effectively overhaul sailing vessels, particularly during the frequent calms off West Africa. 5) The British decided to dispatch part of the anti-slavery squadron to the West Indies and to operate there as well as off Africa. ${ }^{22} 6$ ) The issue may have received more attention because of exaggerated complaints by slave traders themselves, reflecting a movement in the slave states to repeal the prohibition on the Atlantic slave trade. This effort to repeal the ban on the slave trade was itself a part of the 1850 s effort of slaveholders to claim that slavery was a "positive good." ${ }^{33}$

The increased tension over the issue was grounded in a series of specific detentions on the high seas. Further research may reveal a more extensive list, but the British boarded at least the fourteen ships shown in Table 3.

Table 3: Partial list of vessels visited or searched by British 1857-1858

\begin{tabular}{|l|l|l|l|}
\hline \multicolumn{1}{|c|}{ US ship } & \multicolumn{1}{c|}{ Captain } & \multicolumn{1}{c|}{ Ship detaining } & \multicolumn{1}{c|}{ Where detained } \\
\hline Wm. G. Lewis & n.d. & HMS Firefly & Off West Africa \\
\hline Louis McClean & n.d. & HMS Alecto & Off West Africa \\
\hline Clara Williams & n.d. & HMS Alecto & Off West Africa \\
\hline J.W. Reed & n.d. & USS Lushar & Off West Africa \\
\hline Niagara & n.d. & HMS Hecate & Off West Africa \\
\hline Clarendon & Bartlett & n.d. & \\
\hline Robert William & Bray & n.d. & \\
\hline Wm. Chandler & Gage & HMX Styx & West Indies \\
\hline
\end{tabular}

19 "The Right of Visit," New York Times, 11 August 1858.

20 DuBois makes the points about increased prices in Cuba and the United States stimulating the trade.

21 “The African Slave Trade," New York Herald, 1 April 1857; DuBois, pp. 179-80, note 41. One estimate showed 15,000 slaves imported directly to the United States in 1859. DuBois, 182.

22 Vice President Breckinridge saw the exercise of searches in the West Indies as particularly offensive-it was an "American sea." Noted in "Political Review: The Administration Defended: Speech of Vice-President Breckinridge, at Florence Ky," New York Times, 29 July 1858.

23 The last two factors as noted in New York Times, 1 July 1858; also DuBois, chapter 11, esp. 172-176. 


\begin{tabular}{|l|l|l|l|}
\hline Martha Gilchrist & Rawley & HMS Styx & West Indies \\
\hline Tropic Bird & n.d. & HMS Jasper & West Indies \\
\hline N.B. Borden & n.d. & HMS Styx & West Indies \\
\hline Cortes & n.d. & HMS Forward & West Indies \\
\hline Chapman & n.d. & n.d. & \\
\hline Brownsville & n.d. & n.d. & \\
\hline
\end{tabular}

Source: compiled from New York Times reports, 22 April, 14 and 17 May, 4 June, 1858. "n.d." = no data

After the flurry of press concern in the spring of 1858 over these repeated affronts to American honor, the issue once again subsided, and there were only scattered further reports of British searches of ships flying (honestly or not) the U.S. flag. The settlement of the revived dispute came when on 17 June 1858, a discussion in the British Parliament focused on U.S. concern over the right of search, Several members of Parliament made it clear that Britain recognized that there was no right of search in time of peace, but that inspection of papers to ensure that a flag was legitimate had to be carried out, or all sorts of pirates and smugglers would use false flags, knowing they could never be boarded to determine if the flag was legitimate. Although this had always been the position of the British, the explicit recognition in Parliament that there was no "Right of Search" in time of peace satisfied some Northern editorialists, and according to reports, President Buchanan and even his testy secretary of state,Lewis Cass. ${ }^{24}$ At least, the U.S. politicians who had taken the aggressive and outraged posture on the issue could now claim that the British had conceded that they had no right of search in peacetime.

The British indicated that while they accepted the U.S. position, they hoped to work out some practical means of determining the legitimacy of the flag, without giving offense. A British suggestion that a man of war's boat could approach alongside the suspected vessel and request the papers to be handed down (without boarding) was rejected by the United States. ${ }^{25}$

Secretary Cass, in his complaint to the British, stated that, like policemen, naval officers could only visit a ship to confirm the legitimacy of the flag, and only if there was reasonable suspicion that the flag was misused. ${ }^{26}$ Cass admitted that the legitimacy of the flag could only be determined by examining papers, but if a ship was wrongly boarded, the boarding officer and the British Government would be liable for both the financial damage from delay, and a full diplomatic apology would be expected. This communication appeared to provide a final way through the impasse - indicating that, officially, the United States government would not object if a search revealed that a flag had been falsely employed. Although American editorialists believed the British had stopped many innocent vessels, such complaints greatly diminished after the exchange of notes.

The Buchanan administration began to employ steamers and the U.S. naval

24 New York Times, 1 and 3 July 1858.

25 "Right of Search-The Present State of the Question," New York Times, 21 July, 1858.

26 "The Last British Outrage_-The Right of Search Again," New York Times, 10 February 1859. 
squadron was somewhat more active in 1859-1860 in apprehending ships, taking 12 vessels with more than 3,000 slaves aboard. ${ }^{27}$ The number of reported English-on-American-flag incidents declined, although from time to time, one would still make the news. One of the last was in 1859, when the New York Times reported a "British Outrage," (noting the phrase with quote marks in the headline), when the steamer HMS Viper overhauled, examined, evacuated, and burned, the brigantine Rufus Soule, off West Africa on 11 or 12 October 1858 , later landing the crew on a beach. A ship of the U.S. West African Squadron rescued the stranded mariners. The news of the event did not reach the United States until February 1859. In that case, the captain of the brigantine had tossed his papers overboard, certainly an indication they were fraudulent, in the opinion of Lieutenant Commander Austin B. Hodkinton, commander of the British steamer. ${ }^{28}$

Although even the rather calm New York Times commented on this "outrage," the episodes no longer raised the specter of a casus belli, and the United States press turned its attention to the impending internal crisis, with John Brown's raid in the fall of 1859. The possible casus belli derived from exercise of the right of search had in fact only briefly subsided. It arose again during the U.S. Civil War in another guise.

In an episode that falls beyond the scope of this article, U.S. naval officers from the USS San Jacinto detained, and then boarded and searched the British mail packet ship Trent, on 8 November 1861. That event suddenly reversed the nations' roles on the right of search issue. U.S. Navy Captain Charles Wilkes removed from the Trent and detained James Mason and John Slidell, diplomatic officers of the Confederacy. In the resolution of the case, Lincoln and his secretary of state, William Seward, had to admit that the detention of Mason and Slidell was on shaky legal grounds since it represented an exercise of the right of search, a practice Americans had protested since the Chesapeake Affair of 1807, and as shown here, repeatedly in the $1840 \mathrm{~s}$ and $1850 \mathrm{~s}^{29}$

After the United States released Mason and Slidell, the Lincoln administration signed a treaty on 7 June 1862, with Great Britain that granted a mutual limited right of search to assist in suppression of the slave trade. Under this agreement, ships of either government were authorized to search suspected slave trade vessels on the high seas, and near certain specified coasts. If the ships were found to be slavers, or were equipped as slavers, they could be sent to mixed courts set up in New York, in Sierra Leone, or at the Cape of Good Hope. The area opened to this special right of Search was extended in 1863. ${ }^{30}$ Combined with other measures, including a reinforced U.S. African Squadron, the slave trade came to a virtual stop and the right of search of suspected slave ships dropped out of sight as a bone of contention between the two nations.

27 DuBois, 187.

28 "Another "British Outrage," New York Times, 9 February 1859. By putting the term in quotation marks, the Times editors were probably indicating a degree of disdain for the concept of such searches constituting true offenses that would rise to the level of "outrage."

29 The extensive literature on the Trent affair is still growing. A standard work is Gordon H. Warren, Fountain of Discontent: The Trent Affair and Freedom of the Seas (Boston: Northeastern University Press, 1981).

30 DuBois, p. 192, note 95 citing: U.S. Statutes at Large, XII, 531. 